\title{
Pengaruh Model Pembelajaran Siklus Belajar 5E Berbantuan Media Gambar Terhadap Hasil Belajar IPA
}

\author{
Md. A. Aditia ${ }^{*}$, I Gd. Margunayasa², N. Nym. Kusmariyatni ${ }^{3}$ \\ 1,2,3 Jurusan Pendidikan Guru Sekolah Dasar (PGSD), Universitas Pendidikan Ganesha, Singaraja, Indonesia.
}

\author{
A R T I C L E I N F O \\ Article history: \\ Received 20 February 2018 \\ Received in revised form \\ 08 March 2018 \\ Accepted 19 April 2018 \\ Available online 22 May \\ 2018 \\ Kata Kunci: \\ 5E, hasil belajar IPA \\ Keywords: \\ Learning Cycle 5E, learning \\ outcome
}

\begin{abstract}
A B S T R A K
Penelitian ini bertujuan untuk mengetahui perbedaan hasil belajar IPA antara kelompok siswa yang dibelajarkan dengan model pembelajaran Siklus Belajar 5E berbantuan media gambar dan kelompok siswa yang dibelajarkan dengan pembelajaran konvensional pada siswa kelas V SD di Gugus IV Kecamatan Gianyar Tahun Pelajaran 2017/2018. Jenis penelitian ini adalah penelitian eksperimen semu dengan rancangan non-equivalent posttest only control group design. Populasi penelitian ini adalah siswa kelas V SD di Gugus IV Kecamatan Gianyar Tahun Pelajaran 2017/2018 yang berjumlah 131 orang. Pengambilan sampel menggunakan teknik simple random sampling dengan cara undian. Sampel penelitian yaitu siswa kelas V SD Negeri 3 Samplangan yang berjumlah 17 orang dan siswa kelas V SD Negeri 2 Beng yang berjumlah 17 orang. Data hasil belajar IPA dikumpulkan menggunakan tes objektif berbentuk pilihan ganda. Data yang diperoleh dianalisis dengan menggunakan statistik deskriptif dan statistik inferensial yaitu uji-t. Hasil analisis uji-t diperoleh t hitung 4,01 dan tabel 2,037. Terdapat perbedaan yang signifikan hasil belajar IPA antara kelompok siswa yang dibelajarkan dengan model pembelajaran Siklus Belajar $5 \mathrm{E}$ berbantuan media gambar dan kelompok siswa yang dibelajarkan dengan pembelajaran konvensional
\end{abstract}

\section{A B S T R A C T}

The research aimed to determine the differences of Science learning outcomes between students who were given Learning Cycle 5E model with the help of picture media and students who were given conventional learning in the fifth-grade students in Cluster IV District of Gianyar, Gianyar regency in the academic year 2017/2018. This research was quasi-experimental design and used post-test only control group design. The population of this research was all of the fifth-grade students in Cluster IV District of Gianyar, Gianyar regency in the academic year 2017/2018 which consisted 131 people. Sampling used simple random sampling technique by lottery. The samples of this research were 17 fifth grade students of SD (Elementary) Negeri 3 Samplangan and 17 fifth grade students of SD (Elementary) Negeri 2 Beng. The student science score as the data of this research was collected by using the objective test in the form of multiple choice. The data obtained were analyzed by using descriptive statistics and inferential statistics (t-test). The result of t-test analysis obtained t count 4,01 and t table $=2,037$. There were significant differences of Science learning outcomes between students who were given Learning Cycle 5E model with the help of picture media and the students who were given conventional. 


\section{Pendahuluan}

Indonesia merupakan salah satu negara berkembang di kawasan Asia Tenggara. Negara berkembang tentunya memerlukan sumber daya manusia yang berkualitas agar pembangunan berjalan dengan baik. Pendidikan merupakan salah satu faktor yang mempengaruhi sumber daya manusia. Pendidikan yang berkualitas akan menghasilkan sumber daya manusia yang berkualitas. Sumber daya manusia dipandang berkualitas, apabila generasi muda memiliki kecerdasan, keahlian, dan akhlak yang baik. Sistem pendidikan yang bermutu diindikasikan dengan adanya pembelajaran yang inspiratif, interaktif, menantang, dan memotivasi peserta didik untuk berpartisipasi secara aktif.

Proses pembelajaran tidak bisa lepas dari keberadaan guru. Rusman (2016) menyatakan bahwa pembelajaran adalah proses interaksi antara siswa dengan guru pada suatu lingkungan belajar. Pembelajaran dapat berlangsung apabila ada keterlibatan langsung dari guru. "Dalam sistem pembelajaran guru bisa berperan sebagai perencana (planer) atau desiner (designer) pembelajaran, sebagai implementator dan atau keduanya" (Sanjaya, 2015:15). Guru sebagai implementator pembelajaran harus mampu menjalankan rencana yang sudah dirancang, sehingga siswa dapat belajar dengan baik.

Siswa belajar bukanlah sekedar menghafal, tetapi juga mengkonstruksi pengetahuannya. Lefudin (2017) menyatakan pengetahuan bukanlah hasil pemberian dari orang lain seperti guru, tetapi hasil dari proses konstruksi yang dilakukan setiap individu. Proses konstruksi pengetahuan berkaitan dengan teori pembelajaran konstruktivis. Slavin (2011) menyatakan teori pembelajaran konstruktivis adalah teori yang menyatakan bahwa pebelajar harus menemukan dan mengubah informasi yang rumit, dengan memeriksa informasi baru terhadap aturan lama. Teori konstruktivis mengungkapkan bahwa keaktifan siswa sangat menentukan dalam mengembangkan pengetahuannya. Mata pelajaran yang dapat dibelajarkan dengan berlandaskan pada teori kontruktivis adalah IPA. Menurut Hamdu (2011) IPA sebagai salah satu mata pelajaran di sekolah, dapat memberikan peranan dan pengalaman bagi siswa.

Menurut Collete \& Chiappetta (dalam Riastini, 2016:2) IPA adalah studi tentang alam dalam upaya untuk memahami dan menciptakan pengetahuan baru yang memberikan kekuatan prediksi dan aplikasi. Samatowa (2010) menyatakan IPA merupakan ilmu tentang berbagai gejala alam yang disusun secara sistematis yang didasarkan pada hasil percobaan dan pengamatan oleh manusia. Berdasarkan beberapa pendapat tersebut, dapat disimpulkan bahwa IPA merupakan ilmu pengetahuan mengenai gejala-gejala alam yang diperoleh dari percobaan dan nantinya dapat digunakan sebagai pijakan dalam menciptakan pengetahuan baru.

Pembelajaran IPA di sekolah dasar menuntut siswa untuk menemukan sendiri suatu konsep tentang fenomena alam. Ketika siswa menemukan suatu permasalahan, maka siswa akan mencari dan menyelidiki sendiri untuk menuju pemecahan masalah. "Pembelajaran IPA pada jenjang pendidikan dasar harus mampu membekali siswa dengan seperangkat kompetensi dan keterampilan serta nilai yang dibutuhkan oleh mereka untuk mengenal diri, lingkungan, dan tantangan masa depan yang akan dihadapi" (Agustina \& Tika, 2013:257). Pembelajaran IPA tidak hanya menitikberatkan pada penguasaan pengetahuan saja, tetapi juga merupakan suatu proses mencari tahu. Berkaitan dengan pembelajaran IPA di SD, guru harus menerapkan model-model pembelajaran yang bersifat student center agar pembelajaran IPA menjadi berkualitas.

Pada kenyataannya, menurut hasil literasi Programme for International Students Assessment (PISA) 2015 yang dirilis pada 6 Desember 2016, Indonesia menepati peringkat 62 dari 69 negara yang dievaluasi untuk kategori performa sains (Iswadi, 2016). Peringkat dan rata-rata skor siswa Indonesia dikategorikan pada kelompok penguasaan materi yang rendah. Pembelajaran IPA di Indonesia khususnya pada jenjang SD masih berorientasi pada produk (pengetahuan) saja.

Pembelajaran IPA yang hanya berorientasi pada penguasaan pengetahuan akan mengakibatkan kurang optimalnya pencapaian hasil belajar yang diperoleh siswa. Siswa kelas V SD di gugus IV Kecamatan Gianyar, Kabupaten Gianyar memiliki pencapaian hasil belajar yang kurang optimal. Gugus IV Kecamatan Gianyar terdiri atas tujuh sekolah, yaitu SDN 1 Samplangan, SDN 2 Samplangan, SDN 3 Samplangan, SDN 1 Beng, SDN 2 Beng, SDN 3 Beng, dan MI 45 Gianyar.

Berdasarkan hasil observasi keaktifan siswa dalam pembelajaran IPA di kelas V SD Gugus IV Kecamatan Gianyar, maka diperoleh informasi secara umum sebagai berikut. Pertama, kegiatan mempelajari, mengalami, dan menemukan pengetahuan oleh siswa masih kurang. Kedua, siswa kurang aktif dalam melaksanakan kegiatan untuk memahami pengetahuan seperti mencoba sendiri suatu konsep dengan menjawab soal. Ketiga, siswa kurang mengomunikasikan sendiri hasil pemikirannya yang ditunjukkan dengan sedikitnya siswa yang bersedia menyampaikan pendapat. Keempat, siswa kurang berfikir reflektif, karena hanya beberapa siswa yang bersedia untuk menyimpulkan materi pembelajaran. 
Berdasarkan hasil wawancara dengan guru kelas V SD di Gugus IV Kecamatan Gianyar, maka diperoleh informasi sebagai berikut. Pertama, guru menerapkan pembelajaran konvensional, sehingga metode ceramah digunakan secara dominan dalam pembelajaran. Kedua, siswa kurang menaruh minat pada proses pembelajaran, tercermin dari perilaku siswa yang sering bercanda ketika pembelajaran berlangsung. Ketiga, guru menekankan penguasaan suatu materi dengan cara menghafal, bukan melalui penemuan dan penyelidikan. Keempat, guru kurang menggunakan media pembelajaran

Berdasarkan hasil pencatatan dokumen, maka diperoleh nilai rata-rata siswa di tujuh sekolah yang ada di Gugus IV Kecamatan Gianyar masih berada di bawah KKM. Jumlah siswa yang tidak tuntas belajar IPA juga tergolong banyak. Data tersebut menunjukkan kualitas pembelajaran IPA di tujuh sekolah yang ada di Gugus IV Kecamatan Gianyar masih tergolong rendah.

Penggunaan model pembelajaran memberikan peluang dalam meningkatkan kualitas pembelajaran dan hasil belajar siswa. Salah satu model pembelajaran yang dapat meningkatkan hasil belajar IPA adalah model pembelajaran Siklus Belajar 5E. Menurut Suastra (2013) model pembelajaran Siklus Belajar 5E merupakan salah satu dari model pembelajaran yang merupakan perwujudan dari teori konstruktivis tentang belajar dan pembelajaran dengan asumsi bahwa pengetahuan dibangun dalam pikiran pelajar. Sejalan dengan pendapat tersebut, Shoimin (2016) menyatakan model pembelajaran Siklus Belajar 5E merupakan suatu model pembelajaran yang berpusat pada siswa (student centered) dan sesuai dengan teori belajar yang berbasis konstruktivisme. Sadia (2014) menyatakan model pembelajaran Siklus Belajar 5E sebagai pengembangan dari model siklus belajar eksplorasi, pengenalan konsep dan aplikasi konsep yang berorientasi atau berpedoman pada teori konstruktivis. Berdasarkan pendapat tersebut dapat disimpulkan bahwa model pembelajaran Siklus Belajar 5E merupakan suatu model pembelajaran yang bersifat student centered dan menekankan pada aktivitas siswa dalam membangun sendiri pengetahuannya.

Model pembelajaran Siklus Belajar 5E terdiri atas tahapan pembangkitan minat, eksplorasi, penjelasan, memperluas (elaborasi) dan evaluasi. Model pembelajaran ini dapat digunakan untuk memotivasi siswa dalam memahami gejala-gejala alam yang kompleks melalui pengamatan. Siswa akan memperoleh kesempatan untuk mengemukakan argumentasinya. Setiap model memiliki kelebihan tersendiri yang memunculkan keinginan guru untuk menggunakannya dalam proses pembelajaran.

Kelebihan dapat ditemukaan pada model pembelajaran siklus belajar 5E. Shoimin (2016) menyatakan bahwa penerapan model pembelajaran siklus belajar 5E memiliki beberapa kelebihan yaitu (1) meningkatkan motivasi belajar karena peserta didik dilibatkan secara aktif dalam proses pembelajaran, (2) siswa dapat menerima pengalaman dan dimengerti oleh orang lain, (3) siswa mampu mengembangkan potensi individu yang berhasil dan berguna, kreatif, bertanggung jawab, mengaktualisasikan, dan mengoptimalkan dirinya terhadap perubahan yang terjadi, (4) pembelajaran menjadi lebih bermakna.

Berdasarkan kelebihan-kelebihan model pembelajaran siklus belajar 5E yang dikemukakan oleh Shoimin, dapat dipahami bahwa model pembelajaran siklus belajar 5E cocok digunakan dalam pembelajaran karena menuntut adanya partisipasi dari siswa. Model pembelajaran ini membangkitkan motivasi siswa untuk belajar bermakna. Siswa akan menemukan sendiri suatu konsep sehingga pengetahuannya dapat bertahan lama dan bermanfaat dalam kehidupan sehari-hari. Siswa juga diberikan kesempatan untuk saling menerima pengalaman dari temannya sehingga memperkuat dan memperluas pemahamannya terhadap suatu konsep.

Model pembelajaran Siklus Belajar 5E mendukung penerapan metode ilmiah. Melalui siklus belajar ini siswa secara langsung mengidentifikasi fakta atau fenomena yang ada di kehidupan sehari-hari. Siswa kemudian menganalisis aspek yang mendasarinya, dan akhirnya memiliki pemahaman mendalam tentang fakta atau fenomena yang ada. Penggunaan model ini dalam pembelajaran telah mengimplementasikan ciri IPA, terutama IPA sebagai proses. Pembelajaran harus melibatkan siswa secara aktif dalam melaksanakan penyelidikan kearah penemuan. Selain penggunaan model pembelajaran, penggunaan media pembelajaran juga dipandang penting. Menurut Susilana dan Cepi (2009) dengan menggunakan media pembelajaran, maka hasil belajar siswa akan tahan lama mengendap sehingga kualitas pembelajaran memiliki nilai yang tinggi. Salah satu media pembelajaran yang sering digunakan dan dapat meningkatkan hasil belajar adalah gambar.

Gambar merupakan media yang paling umum digunakan. Siswa lebih menyukai gambar dibanding tulisan-tulisan pada papan tulis, terlebih jika gambar tersebut disajikan dengan menarik. Menurut Susilana dan Cepi (2009) media gambar merupakan media visual yang berupa gambar yang dihasilkan melalui proses fotografi. Misalnya, tentang gambar yang ada kaitannya dengan kompetensi yang akan dibentuk pada siswa atau materi pelajaran yang akan dipelajari siswa. Guru tidak perlu menjelaskan secara panjang lebar beberapa konsep, karena ada gambar yang dapat mewakili hal-hal yang ingin 
disampaikan guru. Pepatah menyatakan "Sebuah gambar mengungkap ribuan kata!" (Dent dan Mike, 2006:94).

Media gambar tergolong media pandang yang tidak diproyeksikan. Gambar dapat mengatasi kesulitan dalam mencari sekaligus menampilkan benda asli di dalam kelas. Buku siswa telah memuat beberapa gambar ilustrasi yang menjelaskan beberapa konsep dan fenomena, namun gambar tersebut sangat terbatas adanya dan terkadang guru perlu memberikan ilustrasi lebih lanjut agar tingkat pemahaman siswa meningkat. Penggunakan media gambar dalam pembelajaran IPA dapat mempermudah dalam menyampaikan materi yang abstrak menjadi lebih realistik. Guru akan mudah menjelaskan suatu materi yang berkaitan dengan lingkungan siswa melalui sebuah gambar yang telah dirancang sebelumnya.

Penelitian yang dilaksanakan oleh Sukarta, dkk. (2015) mengungkapkan bahwa penerapan media gambar pada mata pelajaran sains dapat meningkatkan hasil belajar siswa kelas V SD. Penggunaan media gambar dapat membantu model pembelajaran dalam menghasilkan output yang berkualitas. Berlandaskan pada hal tersebut, maka model pembelajaran Siklus Belajar 5E dapat dikalaborasikan dengan media gambar.

Tujuan penelitian ini adalah mengetahui perbedaan hasil belajar IPA yang signifikan antara kelompok siswa kelas V SD yang dibelajarkan menggunakan model pembelajaran Siklus Belajar 5E berbantuan media gambar dengan kelompok siswa yang dibelajarkan pembelajaran konvensional di SD Gugus IV Kecamatan Gianyar Tahun Pelajaran 2017/2018.

\section{Metode}

Jenis penelitian ini merupakan eksperimen semu (quasi experiment). Rancangan penelitian yang digunakan adalah non-equivalent post test only control group design. Tempat pelaksanaan penelitian ini adalah di Gugus IV Kecamatan Gianyar, Kabupaten Gianyar pada semester II tahun pelajaran 2017/2018. Kelompok eksperimen akan diberikan perlakuan berupa penerapan model pembelajaran Siklus Belajar 5E berbantuan media gambar. Kelompok kontrol dibelajarkan dengan menggunakan pembelajaran konvensional, sehingga tidak diberikan perlakuan khusus.

Populasi dalam penelitian ini adalah siswa kelas V SD di Gugus IV Kecamatan Gianyar Kabupaten Gianyar tahun pelajaran 2017/2018 yang dibelajarkan dengan Kurikulum Tingkat Satuan Pendidikan (KTSP). Gugus ini terdiri dari tujuh sekolah, enam sekolah yang menerapkan Kurikulum Tingkat Satuan Pendidikan (KTSP). Jumlah seluruh siswa dari enam sekolah tersebut adalah 131 siswa. Nilai rata-rata UAS IPA semester I digunakan untuk mengetahui kesetaraan kemampuan akademik siswa kelas V SD di Gugus IV Kecamatan Gianyar. Nilai tersebut diuji kesetaraannya menggunakan ANAVA satu jalur. Uji kesetaraan dilakukan menggunakan bantuan SPSS 21.0 for Windows. Berdasarkan hasil uji kesetaraan, maka dapat dinyatakan bahwa nilai signifikansi 0,942 lebih besar dari 0,05. Nilai rata-rata UAS IPA siswa kelas V SD Gugus IV Kecamatan Gianyar setara (sama).

Pemilihan sampel yang digunakan sebagai kelas eksperimen dan kelas kontrol menggunakan teknik random sampling acak. Cara undian digunakan dalam pemilihan sampel tersebut. Enam kelas anggota populasi akan dipilih dua kelas yaitu kelas eksperimen dan kelas kontrol melalui undian yang akan dijadikan sampel penelitian. Siswa kelas V SDN 3 Samplangan terpilih sebagai kelompok eksperimen dan siswa kelas V SDN 2 Beng terpilih sebagai kelompok kontrol.

Data yang dikumpulkaan dalam penelitian ini adalah data hasil belajar siswa kelas V. Metode yang digunakan untuk mengumpukan data hasil belajar IPA adalah metode tes. Metode tes dalam kaitannya dengan penelitian ialah cara memperoleh data yang berbentuk suatu tugas yang dilakukan atau dikerjakan oleh seseorang atau sekelompok orang yang dites. Tes tersebut dapat menghasilkan suatu data berupa skor.

Analisis data yang digunakan dalam penelitian ini adalah analisis deskriptif dan analisis inferensial. Analisis deskriptif dilakukan untuk mengetahui tinggi rendahnya hasil belajar IPA siswa kelompok kontrol dan kelompok eksperimen. Pada analisis deskriptif, masing-masing kelompok data akan dicari mean, modus, median dan standard deviasi. Pada penelitian ini, data disajikan dalam kurva polygon untuk menafsirkan sebaran data hasil belajar IPA.

Uji hipotesis dilakukan setelah uji prasyarat yaitu uji normalitas dan uji homogenitas. Uji normalitas sebaran data dilakukan untuk mengetahui data hasil penelitian berasal dari kelompok data yang berdistribusi normal atau tidak. Normalitas sebaran data diuji dengan menggunakan rumus ChiSquare. Uji homogenitas dilakukan untuk mengetahui sebaran data benar-benar homogen. Uji homogenitas menggunakan uji F. Pengujian hipotesis dilakukan dengan menggunakan uji-t sampel independen (tidak berkorelasi) dengan rumus separated varians. Pemilihan rumus ini mengacu pada ketentuan yaitu, $\mathrm{n} 1=\mathrm{n} 2$, data normal, dan varians homogen. 


\section{Hasil dan Pembahasan}

Data hasil belajar IPA siswa dianalisis dengan analisis deskriptif agar dapat diketahui Mean (M), Median (Md), Modus (Mo), dan Standar Deviasi (SD). Rangkuman hasil analisis data statistik deskriptif disajikan pada tabel 1.

Tabel 1. Deskripsi Data Hasil Belajar IPA Kelompok Eksperimen dan Kelompok Kontrol

\begin{tabular}{ccc}
\hline Statistik & Kelompok Eksperimen & Kelompok Kontrol \\
\hline Mean (M) & 22,29 & 16,35 \\
Median (Md) & 22,81 & 16,00 \\
Modus (Mo) & 23,13 & 15,50 \\
Varians & 15,29 & 14.22 \\
Standar Deviasi & 3,91 & 3.77 \\
\hline
\end{tabular}

Data di atas disajikan dalam bentuk kurva polygon. Hubungan antara mean (M),median (Md), dan modus (Mo) digunakan untuk menentukan kemiringan kurva polygon distribusi frekuensi seperti pada Gambar 1.

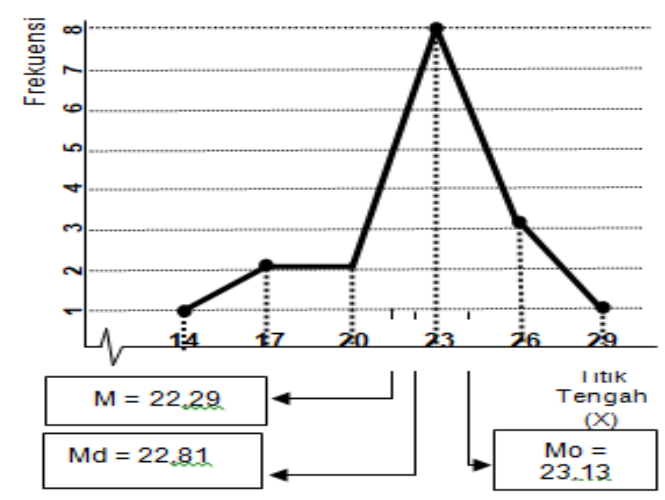

Gambar 1. Kurva Polygon Hasil Belajar IPA Kelompok Eksperimen

Grafik polygon di atas menunjukkan bahwa kurva sebaran skor kelompok eksperimen termasuk kurva juling negatif, karena Mo $>$ Md $>M(23,13>22,81>22,29)$. Kurva juling negatif menunjukkan bahwa sebagian besar skor kelompok eksperimen cenderung tinggi. Skor rata-rata hasil belajar IPA siswa kelompok eksperimen (M) adalah 22,29. Rata-rata hasil belajar IPA siswa kelompok eksperimen termasuk dalam kategori tinggi.

Distribusi frekuensi data hasil belajar IPA kelompok control disajikan pada Gambar 2.

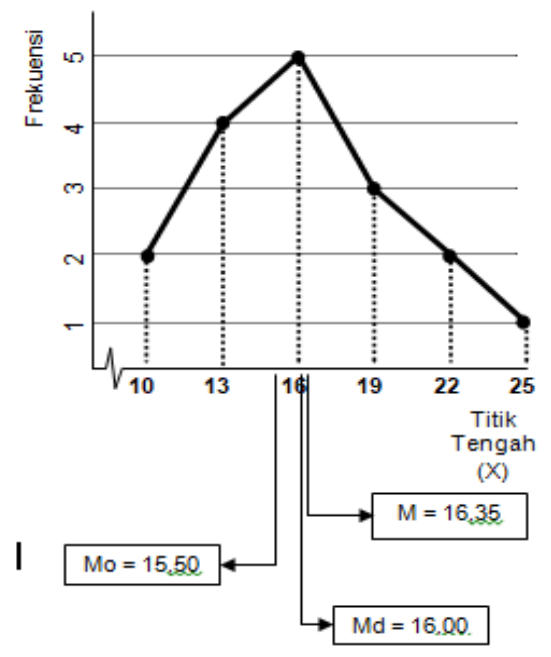

Gambar 2. Kurva Polygon Hasil Belajar IPA Kelompok Kontrol 
Grafik polygon di atas menunjukkan bahwa kurva sebaran skor kelompok kontrol termasuk kurva juling positif, karena $\mathrm{Mo}<\mathrm{Md}<\mathrm{M}(15,50<16,00<16,35)$. Kurva juling positif menunjukkan bahwa sebagian besar skor kelompok eksperimen cenderung rendah. Skor rata-rata hasil belajar IPA siswa kelompok kontrol (M) adalah 16,35. Rata-rata hasil belajar IPA siswa kelompok kontrol termasuk dalam kategori sedang.

Uji prasayarat dilakukan terlebih dahulu sebelum uji hipotesis. Pengujian prasyarat terhadap sebaran data yang meliputi uji normalitas dan homogenitas terhadap data hasil belajar IPA siswa. Perhitungan normalitas dilakukan dengan menggunakan rumus Chi-Square $\left(\chi^{2}\right)$, diperoleh nilai $\chi^{2}$ hitung hasil belajar IPA kelompok eksperimen sebesar 3,398 dan $\chi^{2}$ tabel dengan derajat kebebasan $(\mathrm{dk})=3$ pada taraf signifikansi $5 \%$ adalah 7,81. Nilai $\chi^{2}$ hitung hasil belajar IPA kelompok eksperimen lebih kecil dari $\chi^{2}$ tabel $(3,398<7,81)$, sehingga data hasil belajar IPA kelompok eksperimen berdistribusi normal. Nilai $\chi^{2}$ hitung hasil belajar IPA kelompok kontrol adalah $0,431 \mathrm{dan} \chi^{2}$ tabel dengan derajat kebebasan $(\mathrm{dk})=3$ pada taraf signifikansi $5 \%$ adalah 7,81. Nilai $\chi^{2}$ hitung hasil belajar IPA kelompok kontrol lebih kecil dari $\chi^{2}$ tabel $(0,431<7,81)$, sehingga data hasil belajar IPA kelompok kontrol berdistribusi normal.

Uji homogenitas varians dilakukan terhadap varians pasangan antara kelompok eksperimen dan kelompok kontrol. Hasil belajar IPA kelompok eksperimen dan kelompok kontrol dengan db pembilang = $17-1=16$ dan $\mathrm{db}$ penyebut $=17-1=16$ pada taraf signifikansi $5 \%$ diperoleh $\mathrm{F}_{\text {tabel }}=2,33$ dan $\mathrm{F}_{\text {hitung }}=1,44$. Hasil uji homogenitas menunjukkan bahwa $F_{\text {hitung }}<F_{\text {tabel }}(1,44<2,33)$ sehingga data hasil belajar IPA siswa bersifat homogen.

Hipotesis yang diuji dalam penelitian ini adalah terdapat perbedaan hasil belajar IPA yang signifikan antara kelompok siswa kelas V SD yang dibelajarkan menggunakan model pembelajaran Siklus Belajar $5 E$ berbantuan media gambar dengan kelompok siswa yang dibelajarkan menggunakan pembelajaran konvensional di SD Gugus IV Kecamatan Gianyar Tahun Pelajaran 2017/2018.

Berdasarkan uji prasyarat analisis data, diketahui bahwa data hasil belajar IPA siswa kelompok eksperimen dan kelompok kontrol adalah normal dan homogen. Setelah diperoleh hasil dari uji prasyarat analisis data, dilanjutkan dengan pengujian hipotesis penelitian $\left(\mathrm{H}_{\mathrm{a}}\right)$ dan hipotesis nol $\left(\mathrm{H}_{0}\right)$. Pengujian hipotesis tersebut dilakukan dengan menggunakan uji-t sampel independen (tidak berkorelasi) dengan rumus separated varians.

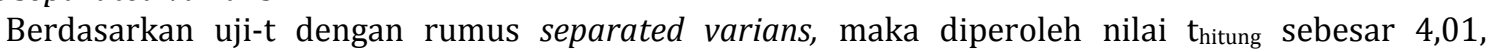
sedangkan nilai $t_{\text {tabel }}$ dengan taraf signifikansi $5 \%$ adalah 2,037. Hal ini berarti $t_{\text {hitung }}$ lebih besar dari $t_{\text {tabel }}$ ( $t_{\text {hitung }}>\mathrm{t}_{\text {tabel }}$ ), sehingga $\mathrm{H}_{0}$ ditolak atau $\mathrm{H}_{\mathrm{a}}$ diterima. Dengan demikian, dapat disimpulkan bahwa terdapat perbedaan hasil belajar IPA yang signifikan antara kelompok siswa yang belajar dengan menggunakan model pembelajaran Siklus Belajar $5 E$ berbantuan media gambar dan kelompok siswa yang dibelajarkan dengan pembelajaran konvensional.

Perbedaan hasil belajar IPA antara kelompok siswa yang dibelajarkan dengan model pembelajaran Siklus Belajar $5 E$ berbantuan media gambar dan kelompok siswa yang dibelajarkan dengan pembelajaran konvensional disebabkan oleh perbedaan sintaks atau langkah-langkah dalam proses pembelajaran. Pembelajaran Siklus Belajar $5 E$ diawali dengan tahapan penarikan minat (engagement), yang merupakan tahap membangkitkan minat dan rasa ingin tahu siswa terhadap materi yang dipelajari. Pada tahapan ini materi yang dipelajari akan dihubungkan dengan kehidupan sehari-hari. Pembangkitan minat dilakukan dengan cara memberikan pertanyaan tentang konsep faktual. Minat dan rasa ingin tahu siswa terhadap materi ajar mempengaruhi hasil belajar. Siswa yang menaruh minat pada materi ajar akan mempermudah dirinya memahami materi ajar, sehingga akan memperoleh hasil belajar yang memuaskan. Menurut Sumar, W.T dan Intan, A.R. (2016) faktor minat dn perhatian dari dalam peserta didik perlu dimunculkan, karena faktor inilah yang sangat menentukan keberhasilan belajar peserta didik. Penelitian yang dilakukan oleh Karina, R.M., dkk. (2017) mengungkapkan bahwa terdapat hubungan yang positif antara minat belajar dengan hasil belajar pada mata pelajaran IPA

Pada tahap eksplorasi (elaboration), siswa bersama anggota kelompoknya mendiskusikan Lembar Kerja Siswa (LKS). Kegiatan belajar yang dilakukan bersama-sama akan mempengaruhi hasil belajar. Menurut Darmadi (2017) siswa dari tingkat kemampuan berbeda dalam setiap kelompok, menggunakan aktivitas belajar yang bervariasi untuk meningkatkan pemahaman mereka terhadap suatu konsep. Pada tahap ini siswa secara aktif untuk memperoleh informasi dengan cara telaah literatur, bertukar pikiran, dan menggabungkan gagasan. Selama proses pembelajaran berlangsung siswa tampak antusias dalam mendiskusikan LKS. Siswa belajar mengorganisasikan diri di dalam suatu kelompok belajar. Kerjasama tampak pada kelompok belajar yang diindikasikan dengan adanya pembagian tugas antar anggota 
kelompok. Pada tahap ini siswa tidak hanya sekedar menghafal, tetapi membangun sendiri pengetahuannya. Konsep yang dipelajari siswa akan lama tersimpan dalam memori atau ingatan. Menurut Rusman (2017) pengetahuan teoritik yang bersifat hafalan mudah lepas dari ingatan seseorang apabila tidak ditunjang dengan pengalaman nyata.

Pada tahap penjelasan (explaination), siswa menjelaskan hasil diskusi kelompoknya. Siswa dapat menjelaskan suatu konsep dengan dengan kalimat sendiri yang disertai bukti maupun penjelasannya. Pada saat proses pembelajaran berlangsung, salah satu perwakilan kelompok menyampaikan hasil diskusi. Siswa yang lain ikut memberikan feedback dengan melontarkan pertanyaan maupun memberikan masukan. Teman-teman dari kelompok penyaji juga ikut membantu untuk memberikan bukti maupun penjelasan. Siswa memperkaya pengetahuan dari pengalaman siswa lainnya. Kegiatan ini dapat melibatkan siswa, baik secara sosial dan mental.

Pada tahap elaborasi (elaborasion), siswa dituntut untuk mampu menerapkan konsep dan keterampilan dalam situasi baru. Siswa yang sudah menguasai beberapa konsep yang diperoleh dari tahapan elaborasi dan penjelasan, mampu menggunakannya sebagai dasar untuk memecahkan suatu permasalahan. Menurut Sanjaya (2017) seseorang akan dapat menguasai kemampuan menerapkan manakala didukung oleh kemampuan dan memahami fakta atau konsep tertentu. Pada saat pembelajaran berlangsung, guru membacakan permasalahan yang berkaitan dengan kehidupan sehari-hari. Siswa bersama anggota kelompoknya berusaha memikirkan solusi terbaik dari permasalahan tersebut. Pada tahap ini guru akan mengetahui tingkat pemahaman konsep siswa.

Berdasarkan tahapan tersebut, tampak jelas bahwa model pembelajaran Siklus Belajar $5 E$ menekankan pada belajar bermakna dan menemukan sendiri suatu pengetahuan atau konsep. Siswa tidak hanya mendengarkan penjelasan dari guru tetapi dapat berperan aktif untuk menggali, menganalisis, dan mengevaluasi pemahamannya terhadap suatu konsep yang dipelajari. Model pembelajaran Siklus Belajar $5 E$ memberikan kesempatan kepada siswa untuk mengoptimalkan cara belajarnya. Siswa menjadi lebih termotivasi untuk belajar dan mengalami sendiri proses belajarnya, sehingga memperoleh hasil belajar yang baik. Penelitian oleh Yuliati (2015) mengungkapkan bahwa penerapan Model Learning Cycle 5E terbukti dapat meningkatkan pembelajaran IPA.

Model pembelajaran Siklus Belajar $5 E$ dalam pelaksanaannya dapat, dikalaborasikan dengan media gambar. Media gambar dapat digunakan untuk mengurangi unsur verbal dari suatu konsep, mempermudah siswa dalam memahami konsep dan menarik perhatian siswa. Pada saat pembelajaran berlangsung media gambar dipergunakan pada tahap penarikan minat, bertujuan untuk memusatkan perhatian siswa dan memudahkan siswa dalam memahami pertanyaan yang diberikan oleh guru. Media gambar juga dipergunakan pada tahap elaborasi, bertujuan untuk memberikan pengalaman belajar yang bermakna pada diri siswa. Siswa tampak antusias dan aktif ketika memanipulasi media gambar yang berkaitan dengan materi ajar. Penelitian oleh Spiani (2015) menyatakan bahwa penggunaan media gambar pada pembelajaran IPA dapat meningkatkan hasil belajar siswa.

Pada pelaksanaan pembelajaran konvensional, siswa berperan sebagai pendengar yang pasif dan mengerjakan tugas yang diinstruksikan oleh guru. Komunikasi hanya terjadi satu arah saja yaitu dari guru ke siswa, sehingga interaksi antar siswa tidak terjadi. Pembelajaran konvensional dalam pelaksanaannya tidak memberikan siswa kesempatan untuk melakukan eksplorasi terhadap pengetahuan yang akan dipelajarinya. Pembelajaran seperti ini membuat siswa kurang memiliki pengetahuan yang bermakna karena pengetahuan yang diperoleh hanya berdasarkan penjelasan materi dari guru.

\section{Simpulan dan Saran}

Berdasarkan hasil penelitian dan pembahasan, dapat disimpulkan bahwa terdapat perbedaan hasil belajar IPA yang signifikan antara kelompok siswa yang dibelajarkan dengan model pembelajaran Siklus Belajar 5E berbantuan media gambar dan kelompok siswa yang dibelajarkan dengan pembelajaran konvensional pada siswa kelas V semester genap tahun pelajaran 2017/2018 di Gugus IV Kecamatan Gianyar, Kabupaten Gianyar.

Saran yang dapat disampaikan berdasarkan penelitian yang telah dilakukan adalah sebagai berikut. (1) Bagi siswa di sekolah dasar, diharapkan selalu mengikuti proses pembelajaran dengan baik sehingga memperoleh hasil belajar yang optimal. (2) Bagi guru yang mengajar IPA di sekolah dasar, model Siklus Belajar 5E berbantuan media gambar dapat diterapkan secara konsisten untuk meningkatkan kualitas dan proses pembelajaran IPA. (3) Bagi Kepala Sekolah, diharapkan untuk menyiediakan media-media pembelajaran yang menunjang penerapan model Siklus Belajar 5E, sehingga guru memiliki banyak pilihan media dalam mengajar. (4) Bagi peneliti yang berminat mengadakan penelitian lebih lanjut tentang model Siklus Belajar 5E berbantuan media gambar, agar menyesuaikan dengan materi ajar demi keberhasilan 
model ini. Bagi peneliti juga dapat menambah variabel dalam melaksanakan penelitian yang melibatkan model Siklus Belajar 5E.

\section{Daftar Rujukan}

Agustina, I G.A.T. dan I.N. Tika. 2013. Konsep Dasar IPA Aspek Fisika dan Kimia. Yogyakarta: Penerbit Ombak.

Agustini. D, I W. Subagia, dan I N. Suardana. 2013. “Pengaruh Model Pembelajaran Sains Teknologi Masyarakat (STM) Terhadap Penguasaan Materi Dan Keterampilan Pemecahan Masalah Siswa Pada Mata Pelajaran IPA Di MTS. Negeri Patas". e-Journal Program Pascasarjana Universitas Pendidikan Ganesha. Volume 3.

Darmadi, H. 2017. Pengembangan Model dan Metode Pembelajaran dalam Dinamika Belajar Siswa.Yogyakarta: Deepublish.

Hamdu, Ghulam dan Lisa Agustina. 2011. "Pengaruh Motivasi Belajar Siswa Terhadap Pestasi Belajar IPA Di Sekolah Dasar". Jurnal Penelitian Pendidikan. Volume 12. Nomor 1.

Iswadi, H. 2016. "Sekelumit Dari Hasil PISA 2015 Yang Baru Dirilis".Tersedia pada www.ubaya.ac.id/2014/content/articles_detail/230/ Overview-of-the-PISA-2015-results-that-havejust-been-Released.html (diakses tanggal 21 Desember 2017).

Lefudin. 2017. Belajar dan Pembelajaran Dilengkapi dengan Model Pembelajaran, Strategi Pembelajaran, Pendekatan Pembelajaran dan Metode Pembelajaran. Yogyakarta: Deepublish.

Llewellyn, D. 2005. Teaching High School Science Through Inquiry. California: Corwin Press.

Riastini, P.N. 2016. Pembelajaran IPA SD. Singaraja: Universitas Pendidikan Ganesha.

Karina, R.M., 2017. “Hubungan Antara Minat Belajar Dengan Hasil Belajar Siswa Dalam Mata Pelajaran IPA Pada Kelas V SD Negeri Gatot Geuceu Aceh Besar". Jurnal Ilmiah Pendidikan Guru Sekolah Dasar. Volume II. Nomor 1.

Rusman. 2017. Belajar \& Pembelajaran: Berorientasi Standar Proses Pendidikan. Jakarta: Kencana.

Samatowa, U. 2010. Pembelajaran IPA di Sekolah Dasar. Jakarta: PT Indeks.

Sani, R.A. 2016. Inovasi Pembelajaran. Jakarta : PT Bumi Aksara.

Sanjaya, W. 2015. Perencanaan \& Desain Sistem Pembelajaran. Jakarta: Prenadamedia Group.

Sanjaya, W. 2017. Paradigma Baru Mengajar. Jakarta: Kencana

Shoimin, A. 2016. 68 Model Pembelajaran Inovatif Dalam Kurikulum. Yogjakarta: Ar-Ruzz Media.

Slavin, E.R. 2011. Psikologi Pendidikan Teori dan Praktik. Jakarta: PT Indeks.

Spiani, F.L., dkk. 2015. "Penggunaan Media Gambar Untuk Meningkatkan Hasil Belajar Siswa dalam Pembelajaran IPA Kelas V". Jurnal Pendidikan dan Pembelajaran. Volume IV, Nomor 6.

Subali, Bambang dan Siti Mariam. 2013. “Pengembangan Kreativitas Keterampilan Proses Sains Dalam Aspek Kehidupan Organisme Pada Mata Pelajaran IPA SD”. Cakrawala Pendidikan. Volume 32. Nomor 3.

Sukarta, dkk. 2015. “Penerapan Media Gambar Pada Mata Pelajaran Sains Dalam Meningkatkan Hasil Belajar Siswa Kelas V SDN Lakea”. Jurnal Kreatif Tadulako Online. Volume V, Nomor 3.

Sumar, W.T dan Intan, A.R. (2016). Strategi Pembelajaran dalam Implementasi Kurikulum Berbasis Soft 
Skill. Yogyakarta: Deepublish.

Susilana, R. dan Cepi R.. 2009. Media Pembelajaran Hakikat, Pengembangan, Pemanfaatan dan Penilaian. Bandung: CV Wacana Prima.

Widiana, I Wayan. 2016. "Pengembangan Asesmen Proyek Dalam Pembelajaran IPA Di Sekolah Dasar”. Jurnal Pendidikan Indonesia. Vol. 5, No. 2. 